\title{
Article
}

\section{Synthesis of dicationic alkyl imidazolium peroxopolyoxotungsten- based phase transfer catalyst and its catalytic activity for olefin epoxidation}

\author{
Jianghao Wu, Pingping Jiang*, Yan Leng, Yuanyuan Ye, Xiaojie Qin \\ The Key Laboratory of Food Colloids and Biotechnology, Ministry of Education, School of Chemical and Material Engineering, Jiangnan University, \\ Wuxi 214122, Jiangsu, China
}

\section{A R T I C L E I N F O}

\section{Article history:}

Received 17 June 2013

Accepted 21 August 2013

Published 20 December 2013

\section{Keywords:}

Dicationic ionic liquid

Polyoxometalate

Olefin

Epoxidation

Phase transfer catalyst

\begin{abstract}
A B S T R A C T
Peroxopolyoxotungsten-based hybrid catalysts modified by dicationic long-chain alkyl imidazolium cations have been synthesized and characterized. The catalytic activity of the catalysts was measured for the epoxidation of olefins with $\mathrm{H}_{2} \mathrm{O}_{2}$. These catalysts proved to be high catalytic activity phase transfer catalysts. In particular, for the catalyst $\left[\mathrm{D}_{12} \mathrm{~min}\right]_{1.5} \mathrm{PW}_{4} \mathrm{O}_{24}$ modified by the dodecyl dicationic imidazolium cation, the conversion of cyclohexene and selectivity for epoxycyclohexane were $97.7 \%$ and $96.3 \%$, respectively. After the reaction, the catalyst could be recovered simply by filtration and reused four times. The conversion of cyclohexene and selectivity for epoxycyclohexane were still $72.4 \%$ and $97.2 \%$, respectively, after recycling the catalyst four times. In addition, this phase transfer catalyst can be applied to the epoxidation of a wide range of olefins.
\end{abstract}

(C) 2013, Dalian Institute of Chemical Physics, Chinese Academy of Sciences. Published by Elsevier B.V. All rights reserved.

\section{Introduction}

Epoxides are valuable organic raw materials and intermediates for fine chemical and pharmaceutical synthesis [1-3]. $\mathrm{H}_{2} \mathrm{O}_{2}$-based catalytic epoxidation efficiency and reusability under mild conditions have received much attention from an economic and environmental point of view [4]. A wide range of catalysts for olefin epoxidation have been described, such as heteroatomic molecular sieves, transition metal (Mo, W, Mn, and V) compounds, and polyoxometalates (POMs) [5-11]. Tungsten-based POM catalysts show high efficiency of hydrogen peroxide use and high selectivity towards epoxides, typically the Venturello-Ishii $\left(\left\{\mathrm{PO}_{4}\left[\mathrm{WO}\left(\mathrm{O}_{2}\right)_{2}\right]_{4}\right\}^{3-}\right)$ species, and have attracted considerable attention as effective catalysts for the $\mathrm{H}_{2} \mathrm{O}_{2}$-based epoxidation of olefins [12,13]. Since Xi et al. [14] reported that quaternary ammonium POMs can be used as reaction-controlled phase-separation catalysts for olefin epoxidation, considerable effort has been focused on modifying POMs with organic species to obtain phase transfer POM-based hybrid catalysts with improved catalytic activity, selectivity, and convenient catalyst recovery and recycling that combine the advantages of both homogeneous and heterogeneous catalysts [15-19].

In this work, we synthesized a series of POM-based ionic hybrid catalysts by combining dicationic long-chain alkyl imidazolium cations with Venturello-Ishii anions. Characterization was performed using Fourier transform infrared (FT-IR) spectroscopy, thermogravimetric analysis (TGA), ${ }^{1} \mathrm{H}$ NMR, and CHN elemental analysis. The obtained hybrid catalysts were used for the solid-liquid-solid phase transfer catalytic epoxidation of

\footnotetext{
*Corresponding author. Tel: +86-510-85917090; Fax: +86-510-85913617; E-mail: ppjiang@jiangnan.edu.cn

This work was supported by the National Key Technology R\&D Program (2012BAD32B03) and the Cooperative Innovation Foundation of Industry, Academy and Research Institutes (BY2013015-10) in Jiangsu Province of China.

DOI: 10.1016/S1872-2067(12)60697-4 | http://www.sciencedirect.com/science/journal/18722067 | Chin. J. Catal., Vol. 34, No. 12, December 2013
} 
olefins with aqueous $\mathrm{H}_{2} \mathrm{O}_{2}$ in different solvents.

\section{Experimental}

\subsection{Preparation of catalysts}

The procedure for the synthesis of the catalysts is shown in Scheme 1. The preparation of $\left[\mathrm{D}_{12} \mathrm{mim}\right]_{1.5} \mathrm{PW}_{4} \mathrm{O}_{24}$ is used as an example.

\subsubsection{Synthesis of $N$-alkylimidazole}

The synthesis of $\mathrm{N}$-dodecylimidazole was used as an example. $\mathrm{N}$-dodecyl bromide (7 g, $28 \mathrm{mmol}$ ) was dissolved in dimethyl formamide (DMF, $25 \mathrm{~mL}$ ) and then added to a solution of the sodium salt of imidazole, which was formed by the reaction of imidazole (2.3 g, $33.9 \mathrm{mmol})$ with sodium hydride $(1.4 \mathrm{~g}, 62$ $\mathrm{mmol}$ ) in DMF (25 mL). The mixture was heated at $60^{\circ} \mathrm{C}$ for 6 $\mathrm{h}$, cooled, and then filtered. The filtrate was washed with brine and water, and then dried with sodium sulfate. The solvent was separated by reduced pressure distillation and $\mathrm{N}$-alkylimidazole was obtained as a pale yellow oily product. ${ }^{1} \mathrm{H}$ NMR $(400$ $\left.\mathrm{MHz}_{\mathrm{CDCl}}\right) \delta=7.45(\mathrm{~s}, 1 \mathrm{H}, \mathrm{CH}), 7.04(\mathrm{~s}, 1 \mathrm{H}, \mathrm{CH}), 6.90(\mathrm{~s}, 1 \mathrm{H}$, $\mathrm{CH}), 3.91\left(\mathrm{t}, J=7.1 \mathrm{~Hz}, 2 \mathrm{H}, \mathrm{CH}_{2}\right), 1.77\left(\mathrm{~m}, J=13.5 \mathrm{~Hz}, 2 \mathrm{H}, \mathrm{CH}_{2}\right)$, $1.27\left(\mathrm{~m}, J=13.1 \mathrm{~Hz}, 18 \mathrm{H}, \mathrm{CH}_{2}\right), 0.88\left(\mathrm{t}, J=6.7 \mathrm{~Hz}, 3 \mathrm{H}, \mathrm{CH}_{3}\right)$.

\subsubsection{Synthesis of dicationic imidazolium ionic liquids}

Dicationic imidazolium ionic liquids were prepared by refluxing $N$-dodecylimidazole $(4.72 \mathrm{~g}, 20 \mathrm{mmol})$ and 1,4-dibromobutane (2.16 g, $10 \mathrm{mmol})$ in isopropanol $(25 \mathrm{~mL})$ at $80{ }^{\circ} \mathrm{C}$ for $24 \mathrm{~h}$. Then, the products were washed with diethyl ether four times under vacuum. ${ }^{1} \mathrm{H}$ NMR $\left(400 \mathrm{MHz}, \mathrm{CDCl}_{3}\right) \delta=10.18$ (s, $\left.2 \mathrm{H}, \mathrm{CH}_{2}\right), 8.12$ (s, 2H, CH), $7.29(\mathrm{~s}, 2 \mathrm{H}, \mathrm{CH}), 4.58\left(\mathrm{~s}, 4 \mathrm{H}, \mathrm{CH}_{2}\right)$, $4.27\left(\mathrm{t}, J=7.5 \mathrm{~Hz}, 4 \mathrm{H}, \mathrm{CH}_{2}\right), 2.19\left(\mathrm{~s}, 4 \mathrm{H}, \mathrm{CH}_{2}\right), 1.90$ (d, $J=6.4 \mathrm{~Hz}$, $\left.4 \mathrm{H}, \mathrm{CH}_{2}\right), 1.25\left(\mathrm{~m}, 36 \mathrm{H}, \mathrm{CH}_{2}\right), 0.88\left(\mathrm{t}, J=6.8 \mathrm{~Hz}, 6 \mathrm{H}, \mathrm{CH}_{3}\right)$.

\subsubsection{Synthesis of dicationic alkyl imidazolium peroxopolyoxo-} tungsten-based catalyst [20]

A suspension of tungstic acid ( $2.50 \mathrm{~g}, 10 \mathrm{mmol})$ in $7.93 \mathrm{~g}$ (70 mmol) of $30 \%$ aqueous $\mathrm{H}_{2} \mathrm{O}_{2}$ was stirred and heated at $60{ }^{\circ} \mathrm{C}$ until a colorless solution was obtained. After filtering and cooling the solution at room temperature, $40 \mathrm{wt} \% \mathrm{H}_{3} \mathrm{PO}_{4}(0.62 \mathrm{~g}$, $2.5 \mathrm{mmol}$ ) was added, and the solution was diluted with $30 \mathrm{~mL}$ of water and then stirred for $30 \mathrm{~min}$. Dicationic imidazolium ionic liquid ( $3.75 \mathrm{mmol})$ in dichloromethane $(40 \mathrm{~mL})$ was added dropwise to the resultant solution with strong stirring over a period of more than $2 \mathrm{~min}$. Stirring was continued for an additional $60 \mathrm{~min}$. The organic phase was then separated, dried over $\mathrm{Na}_{2} \mathrm{SO}_{4}$, filtered, and gently evaporated by reduced pressure distillation on a rotary evaporator under reduced pressure at $40-50{ }^{\circ} \mathrm{C}$, which gave a yellow powder. This catalyst was $\left[\mathrm{D}_{12} \mathrm{mim}\right]_{1.5} \mathrm{PW}_{4} \mathrm{O}_{24}$.

\subsection{Characterization of catalyst structure}

FT-IR spectra were recorded on an ABB FTLA2000 FT-IR spectrometer (Canada) (KBr discs, 4000-500 $\mathrm{cm}^{-1}$ ). TGA was carried out with a METTLER-TOLEDO TGA/1100SF instrument (Switzerland) in $\mathrm{N}_{2}$ at a heating rate of $10{ }^{\circ} \mathrm{C} / \mathrm{min}$. Elemental analyses (C, H, and $\mathrm{N}$ ) were performed on a CHN elemental analyzer (Elementar Vario EL III, Germany). The ${ }^{1} \mathrm{H}$ NMR spectra were recorded on an AVANCE III $400 \mathrm{MHz}$ digital NMR spectrometer (Bruker, Germany) using a $\mathrm{CDCl}_{3}$ solvent.

\subsection{Epoxidation procedure}

Cyclohexene ( $9 \mathrm{mmol}), \mathrm{CH}_{3} \mathrm{CN}(10 \mathrm{~mL})$, and catalyst $(0.1 \mathrm{~g})$ were added to a $25 \mathrm{~mL}$ flask. The reaction started after the addition of aqueous $\mathrm{H}_{2} \mathrm{O}_{2}$ ( $30 \mathrm{wt} \%, 3 \mathrm{mmol}$ ) at $60{ }^{\circ} \mathrm{C}$ within 10 min under vigorous stirring. After the reaction, the product mixture was analyzed by gas chromatography (GC). The catalyst was recovered by filtration immediately after the reaction ready for the next reaction (run). The conversion $(X)$ and selectivity $(S)$ were calculated as follows:

$X=$ (mol epoxide product + mol byproducts) / (mol initial $\left.\mathrm{H}_{2} \mathrm{O}_{2}\right) \times 100 \%$

$S=$ (mol epoxide product) $/$ (mol epoxide product + mol byproducts) $\times 100 \%$

All of the olefin substrates were tested using the same procedure.

\section{Results and discussion}

\subsection{Catalyst structure and thermal stability}

The TGA curves of the catalysts are shown in Fig. 1. The hybrid catalysts were stable up to $200{ }^{\circ} \mathrm{C}$ (region I), indicating that these catalysts are thermally stable. The slight mass loss is due to the removal of the combination water. The mass loss between 250 and $600{ }^{\circ} \mathrm{C}$ is due to decomposition of the organic components in the catalyst (region II), which is consistent with the CHN elemental analysis (Table 1). Thus, these results confirm that the molar of cantion and polyanion of the catalysts is $1.5: 1$, and the hybrids have the chemical formulas shown in Scheme 1.

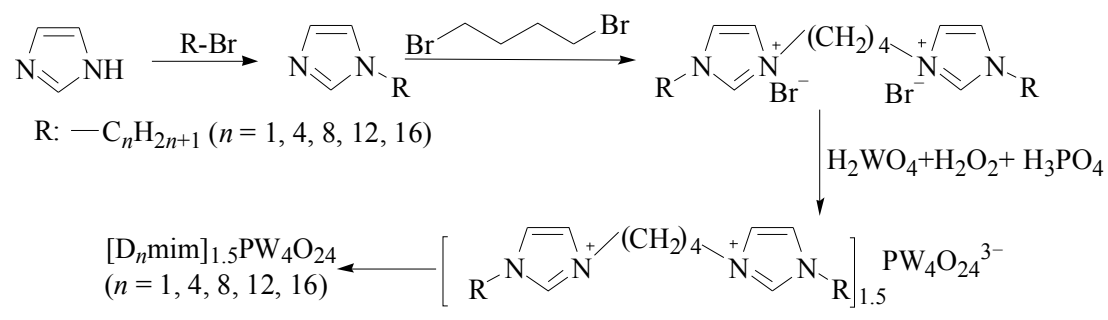

Scheme 1. Typical preparation procedure of the catalysts. 


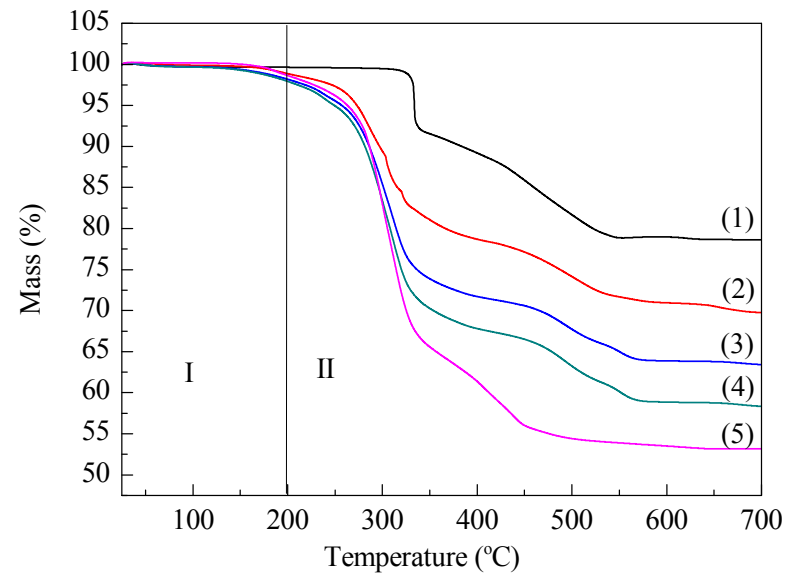

Fig. 1. Thermogravimetric curves of catalysts. (1) $\left[\mathrm{D}_{1} \mathrm{mim}\right]_{1.5} \mathrm{PW}_{4} \mathrm{O}_{24}$; (2) $\left[\mathrm{D}_{4} \mathrm{mim}\right]_{1.5} \mathrm{PW}_{4} \mathrm{O}_{24}$; (3) $\left[\mathrm{D}_{8} \mathrm{mim}\right]_{1.5} \mathrm{PW}_{4} \mathrm{O}_{24}$; (4) $\left[\mathrm{D}_{12} \mathrm{mim}\right]_{1.5} \mathrm{PW}_{4} \mathrm{O}_{24}$; (5) $\left[\mathrm{D}_{16} \mathrm{mim}\right]_{1.5} \mathrm{PW}_{4} \mathrm{O}_{24}$.

Table 1

Results of CHN elemental analysis.

\begin{tabular}{lccc}
\hline \multirow{2}{*}{ Catalyst } & \multicolumn{3}{c}{ Test value (\%)/Theoretical value (\%) } \\
\cline { 2 - 4 } & $\mathrm{C}$ & $\mathrm{H}$ & $\mathrm{N}$ \\
\hline$\left[\mathrm{D}_{1} \mathrm{mim}\right]_{1.5} \mathrm{PW}_{4} \mathrm{O}_{24}$ & $14.42 / 14.60$ & $1.97 / 2.05$ & $5.66 / 5.68$ \\
{$\left[\mathrm{D}_{4} \mathrm{mim}\right]_{1.5} \mathrm{PW}_{4} \mathrm{O}_{24}$} & $19.97 / 20.18$ & $3.12 / 3.02$ & $5.12 / 5.23$ \\
{$\left[\mathrm{D}_{8} \mathrm{mim}\right]_{1.5} \mathrm{PW}_{4} \mathrm{O}_{24}$} & $26.16 / 26.38$ & $3.98 / 4.06$ & $4.85 / 4.73$ \\
{$\left[\mathrm{D}_{12} \mathrm{mim}\right]_{1.5} \mathrm{PW}_{4} \mathrm{O}_{24}$} & $32.74 / 31.51$ & $4.72 / 4.94$ & $4.19 / 4.32$ \\
{$\left[\mathrm{D}_{16} \mathrm{mim}\right]_{1.5} \mathrm{PW}_{4} \mathrm{O}_{24}$} & $34.70 / 35.82$ & $5.32 / 5.74$ & $3.54 / 3.98$ \\
\hline
\end{tabular}

\subsection{FT-IR analysis}

The FT-IR spectra of the hybrid catalysts are shown in Fig. 2. The characteristic bands of the Venturello anion structure $\left\{\mathrm{PO}_{4}\left[\mathrm{WO}\left(\mathrm{O}_{2}\right)_{2}\right]_{4}\right\}^{3-}$ appear at 1077 and $1039(\mathrm{P}-0), 942(\mathrm{~W}=0)$, $889\left(\mathrm{~W}-\mathrm{O}_{\mathrm{b}}-\mathrm{W}\right), 852(\mathrm{O}-0), 811\left(\mathrm{~W}-\mathrm{O}_{\mathrm{c}}-\mathrm{W}\right)$, and $591 \mathrm{~cm}^{-1}$ $\left(\mathrm{W}-\mathrm{O}_{\mathrm{b}}-\mathrm{O}\right)$. For all the hybrid samples, featured peaks as well as bands of organic groups can be clearly observed. For example, [D $\left.{ }_{12} \mathrm{mim}\right]_{1.5} \mathrm{PW}_{4} \mathrm{O}_{24}$ has bands at 3145 and $3099 \mathrm{~cm}^{-1}$ that can be attributed to the stretching vibration of the $\mathrm{C}-\mathrm{H}$ bond in

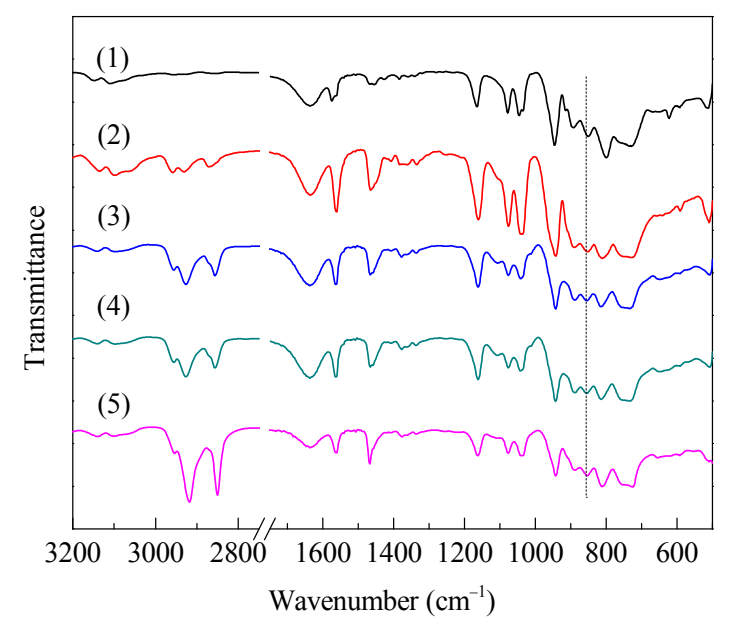

Fig. 2. FT-IR spectra of catalysts. (1) $\left[\mathrm{D}_{1} \mathrm{mim}\right]_{1.5} \mathrm{PW}_{4} \mathrm{O}_{24} ; \quad$ (2) $\left[\mathrm{D}_{4} \mathrm{mim}\right]_{1.5} \mathrm{PW}_{4} \mathrm{O}_{24} ;(3)\left[\mathrm{D}_{8} \mathrm{mim}\right]_{1.5} \mathrm{PW}_{4} \mathrm{O}_{24} ;(4)\left[\mathrm{D}_{12} \mathrm{mim}\right]_{1.5} \mathrm{PW}_{4} \mathrm{O}_{24} ;$ (5) $\left[\mathrm{D}_{16} \mathrm{mim}\right]_{1.5} \mathrm{PW}_{4} \mathrm{O}_{24}$ imidazole, peaks at 2960,2918, and $2848 \mathrm{~cm}^{-1}$ that are due to the stretching vibration of the $\mathrm{C}-\mathrm{H}$ bond in the alkyl chain, and peaks at 1562 and $1464 \mathrm{~cm}^{-1}$ that are due to the skeletal vibration of the imidazole ring. These observations confirm that the combination of dicationic alkyl imidazolium organic cations with the Venturello anion $\left(\left\{\mathrm{PO}_{4}\left[\mathrm{WO}\left(\mathrm{O}_{2}\right)_{2}\right]_{4}\right\}^{3-}\right)$ via ionic bonds produced a new type of organic POM salt. For all these catalysts, the bands at $852 \mathrm{~cm}^{-1}$ can be attributed to the peroxooxygen band $(v(0-0))$ of the peroxo-W species, which is regraded as the active center for $\left\{\mathrm{PO}_{4}\left[\mathrm{WO}\left(\mathrm{O}_{2}\right)_{2}\right]_{4}\right\}^{3-}$-based epoxidation reactions $[21,22]$ and demonstrates that the catalysts we prepared have catalytic activity centers.

\subsection{Catalytic performance of different catalysts}

The results using different peroxophosphatotungstate-based hybrid catalysts for the epoxidation of cyclohexene in acetonitrile with $\mathrm{H}_{2} \mathrm{O}_{2}$ are shown in Table 2. The results show that the carbon chain length of the R groups attached to the imidazolium ions significantly affects the catalyst activity for epoxidation. [ $\left.\mathrm{D}_{1} \mathrm{mim}\right]_{1.5} \mathrm{PW}_{4} \mathrm{O}_{24}$ showed $69.2 \%$ conversion and $98.6 \%$ selectivity. When the carbon chain length was increased from 4 to 12 (from $\left[\mathrm{D}_{4} \mathrm{mim}\right]_{1.5} \mathrm{PW}_{4} \mathrm{O}_{24}$ to [D $\left.\left.\mathrm{D}_{12 \mathrm{mim}}\right]_{1.5} \mathrm{PW}_{4} \mathrm{O}_{24}\right)$, the conversion of cyclohexene increased from $78.5 \%$ to $97.7 \%$, while the selectivity of both catalysts was greater than $96 \%$. This means that the longer the alkyl chain of the $\mathrm{R}$ group of the imidazolium ions, the more likely it is that the reactant comes in contact with the catalytic center. However, when the carbon chain length was further increased, the catalytic performance of the catalyst ([D $\left.16 \mathrm{mim}_{1.5} \mathrm{PW}_{4} \mathrm{O}_{24}\right)$ decreased (89.2\% conversion and $97.2 \%$ selectivity). This lower catalytic performance may result from the long alkyl chain increasing the catalyst molecule steric hindrance and mass transfer resistance between the reactants and catalyst. As can be seen from the above results, $\left[\mathrm{D}_{12} \mathrm{mim}\right]_{1.5} \mathrm{PW}_{4} \mathrm{O}_{24}$ gives the best performance, with $97.7 \%$ conversion and $96.3 \%$ selectivity.

Moreover, the catalysts prepared showed different catalytic behavior during the reaction. $\left[\mathrm{D}_{4} \mathrm{mim}\right]_{1.5} \mathrm{PW}_{4} \mathrm{O}_{24}$, $\left[\mathrm{D}_{8} \mathrm{mim}\right]_{1.5} \mathrm{PW}_{4} \mathrm{O}_{24},\left[\mathrm{D}_{12} \mathrm{mim}\right]_{1.5} \mathrm{PW}_{4} \mathrm{O}_{24}$, and $\left[\mathrm{D}_{16} \mathrm{mim}\right]_{1.5} \mathrm{PW}_{4} \mathrm{O}_{24}$ all showed phase transfer behavior during the reaction process, with the switch from heterogeneous to homogeneous catalysis clearly observed. At the beginning of the reaction, the catalyst itself was solid at bottom (Fig. 3(a)), but when $\mathrm{H}_{2} \mathrm{O}_{2}$ was added to the reaction system the catalyst gradually dissolved in the medium to form a homogeneous mixture (Fig. 3(b)). After the reaction was complete, the system became turbid, and the cata-

Table 2

Epoxidation of cyclohexene with $\mathrm{H}_{2} \mathrm{O}_{2}$ and various catalysts.

\begin{tabular}{lcc}
\hline Catalyst & $X / \%$ & $S / \%$ \\
\hline$\left[\mathrm{D}_{1} \mathrm{mim}\right]_{1.5} \mathrm{PW}_{4} \mathrm{O}_{24}$ & 69.2 & 98.6 \\
{$\left[\mathrm{D}_{4} \mathrm{mim}\right]_{1.5} \mathrm{PW}_{4} \mathrm{O}_{24}$} & 78.5 & 97.9 \\
{$\left[\mathrm{D}_{8} \mathrm{mim}\right]_{1.5} \mathrm{PW}_{4} \mathrm{O}_{24}$} & 92.1 & 96.4 \\
{$\left[\mathrm{D}_{12} \mathrm{mim}\right]_{1.5} \mathrm{PW}_{4} \mathrm{O}_{24}$} & 97.7 & 96.3 \\
{$\left[\mathrm{D}_{16} \mathrm{mim}\right]_{1.5} \mathrm{PW}_{4} \mathrm{O}_{24}$} & 89.2 & 97.2 \\
\hline
\end{tabular}

Reaction conditions: $0.1 \mathrm{~g}$ catalyst, $9 \mathrm{mmol}$ cyclohexene, $3 \mathrm{mmol} \mathrm{H}_{2} \mathrm{O}_{2}$, $10 \mathrm{~mL}$ acetonitrile, $60^{\circ} \mathrm{C}, 4 \mathrm{~h}$. 


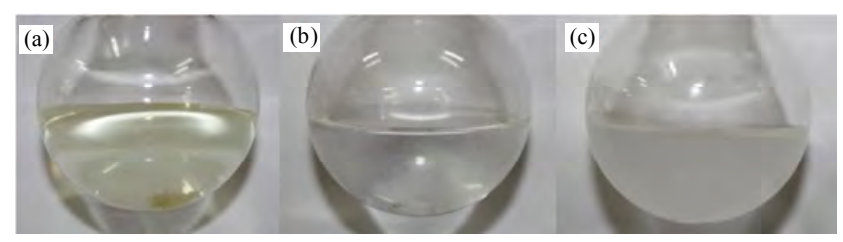

Fig. 3. Photographs of the epoxidation of cyclohexene with $\mathrm{CH}_{3} \mathrm{CN}$ over the $\left[\mathrm{D}_{12} \mathrm{mim}\right]_{1.5} \mathrm{PW}_{4} \mathrm{O}_{24}$ catalyst. (a) $\left[\mathrm{D}_{12} \mathrm{mim}\right]_{1.5} \mathrm{PW}_{4} \mathrm{O}_{24}$ solid at bottom; (b) Homogeneous phase during the reaction; (c) At the end of reaction and the catalyst has precipitated.

lyst finally separated from the media at room temperature (Fig. $3(\mathrm{c})$ ). However, $\left[\mathrm{D}_{1} \mathrm{mim}\right]_{1.5} \mathrm{PW}_{4} \mathrm{O}_{24}$ was a heterogeneous catalyst in the reaction, which may explain why the $\left[\mathrm{D}_{1} \mathrm{mim}\right]_{1.5} \mathrm{PW}_{4} \mathrm{O}_{24}$ epoxidation activity is lower than the other catalysts.

As in the chloroform solvent, quaternary ammonium heteropolyoxotungstates can react with $\mathrm{H}_{2} \mathrm{O}_{2}$ to form peroxide reactive intermediates that are soluble in the reaction system. The peroxide reactive intermediates gradually return to the original catalyst structure as $\mathrm{H}_{2} \mathrm{O}_{2}$ is used up in the epoxidation reaction, and then precipitate at the end of the reaction, thereby forming a reaction-controlled phase transfer system [14]. To confirm that the phosphotungstate catalysts we prepared react with $\mathrm{H}_{2} \mathrm{O}_{2}$ to form the soluble peroxide reactive intermediates $\left\{\mathrm{PO}_{4}\left[\mathrm{WO}\left(\mathrm{O}_{2}\right)_{2}\right]_{4}\right\}^{3-}$ in acetonitrile, the hybrid-catalyzed epoxidation was confirmed by the IR measurement of [D ${ }_{12}$ mim $]_{1.5} \mathrm{PW}_{4} \mathrm{O}_{24}$ after reacting with $30 \% \mathrm{H}_{2} \mathrm{O}_{2}$ in $\mathrm{CH}_{3} \mathrm{CN}$ at $60{ }^{\circ} \mathrm{C}$ for $10 \mathrm{~min}$, which mimics the practical reaction but in the absence of any olefin substrate (Fig. 4(2)). Compared with the FT-IR spectrum of the fresh catalyst (Fig. 4(1)), the peak at 840 $\mathrm{cm}^{-1}$ (peroxo-oxygen band, $v(\mathrm{O}-0)$ ) of the catalyst treated by $\mathrm{H}_{2} \mathrm{O}_{2}$ was significantly larger. This means that after $\mathrm{H}_{2} \mathrm{O}_{2}$ treatment the catalyst forms peroxide reactive intermediates $\left\{\mathrm{PO}_{4}\left[\mathrm{WO}\left(\mathrm{O}_{2}\right)_{2}\right]_{4}\right\}^{3-}$. Therefore, the catalyst gradually dissolved to form a homogeneous system when the $\mathrm{H}_{2} \mathrm{O}_{2}$ was added to the solution. However, the catalyst separates from the reaction media and must be cooled to room temperature after the reaction is completed. This behavior is different from that discussed in the literature [14]. Therefore, dicationic alkyl imidazolium peroxopolyoxotungsten-based catalysts cause a tempera-

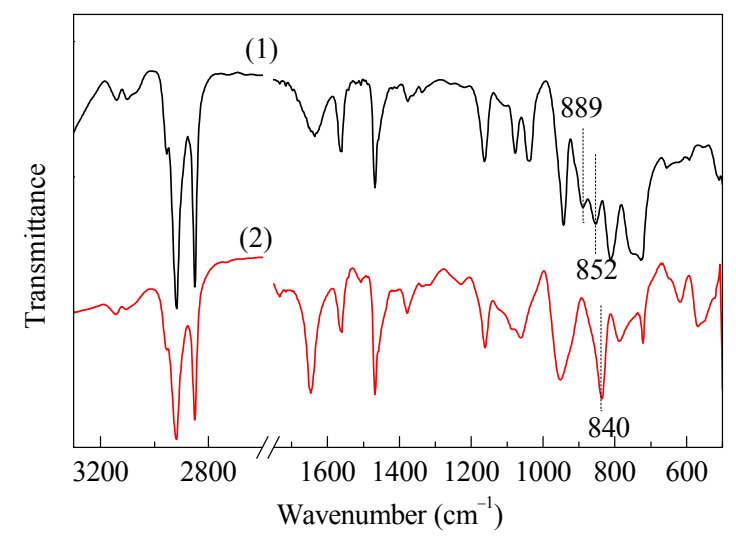

Fig. 4. FT-IR spectra of catalysts. (1) $\left[\mathrm{D}_{12} \mathrm{mim}\right]_{1.5} \mathrm{PW}_{4} \mathrm{O}_{24}$; $\left[\mathrm{D}_{12} \mathrm{mim}\right]_{1.5} \mathrm{PW}_{4} \mathrm{O}_{24}$ treated by $\mathrm{H}_{2} \mathrm{O}_{2}$.
Table 3

Effect of reaction media of cyclohexene epoxidation reaction.

\begin{tabular}{|c|c|c|c|c|}
\hline \multirow{2}{*}{ Solvent } & \multicolumn{2}{|c|}{ Catalyst state } & \multirow{2}{*}{$X / \%$} & \multirow{2}{*}{$S / \%$} \\
\hline & During reaction & After reaction & & \\
\hline Acetonitrile & soluble & insoluble & 97.7 & 96.3 \\
\hline Ethyl acetate & soluble & insoluble & 97.6 & 97.1 \\
\hline Dichloromethane & soluble & insoluble & 98.8 & 96.6 \\
\hline 1,2-Dichloroethane & soluble & insoluble & 98.3 & 96.2 \\
\hline Cyclohexane & insoluble & insoluble & 88.2 & 98.1 \\
\hline
\end{tabular}

Reaction conditions: 0.1 g catalyst, $9 \mathrm{mmol}$ cyclohexene, $3 \mathrm{mmol} \mathrm{H}_{2} \mathrm{O}_{2}$, $10 \mathrm{~mL}$ solvent, $60^{\circ} \mathrm{C}, 4 \mathrm{~h}$.

ture-controlled phase transfer system and combine the advantages of both homogeneous and heterogeneous catalysts.

\subsection{Catalytic performance of $\left[\mathrm{D}_{12} \mathrm{mim}\right]_{1.5} \mathrm{PW}_{4} \mathrm{O}_{24}$ in different solvents and reaction phases}

Table 3 shows the results of the effect of different solvents on the $\left[\mathrm{D}_{12} \mathrm{mim}\right]_{1.5} \mathrm{PW}_{4} \mathrm{O}_{24}$ catalyzed epoxidation of cyclohexene. When acetonitrile, ethyl acetate, dichloromethane, and 1,2-dichloroethane were used as the solvent, phase transfer was observed, and cyclohexene conversion and selectivity for epoxide cyclohexane were both greater than 96\%. Furthermore, when ethyl acetate was used as the solvent, the reaction showed temperature-controlled phase transfer. However, when dichloromethane and 1,2-dichloroethane were used as the solvent, the catalyst gradually precipitated when the $\mathrm{H}_{2} \mathrm{O}_{2}$ was used up (Fig. 5). As a result, the system becomes turbid, indicating completion of the epoxidation reaction, which does not need to be cooled to room temperature. The reaction process is a solid-liquid-solid phase-separation catalytic process forming a reaction-controlled phase transfer system, which is different to when ethyl acetate and acetonitrile were used as the solvent. In addition, $\left[\mathrm{D}_{12} \mathrm{mim}\right]_{1.5} \mathrm{PW}_{4} \mathrm{O}_{24}$ did not dissolve when cyclohexane was used as the solvent, which may be due to active peroxy intermediate that is difficult to dissolve in low polarity solvents, resulting in low catalytic activity. Therefore, the dicationic alkyl imidazolium peroxopolyoxotungsten-based catalysts we have designed and synthesized can act as temperature-controlled phase transfer catalysts in common polar organic solvents and reaction-controlled phase transfer catalysts in weakly polar organic solvents.

\subsection{Catalyst reusability}

It is convenient to recover the hybrid catalyst by filtration or centrifugation after a reaction, and then the solid catalyst can

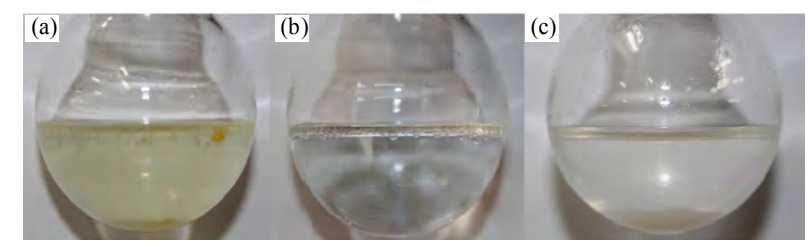

Fig. 5. Photographs of the epoxidation of cyclohexene with $\mathrm{CH}_{2} \mathrm{Cl}_{2}$ over the $\left[\mathrm{D}_{12} \mathrm{mim}\right]_{1.5} \mathrm{PW}_{4} \mathrm{O}_{24}$ catalyst. (a) $\left[\mathrm{D}_{12} \mathrm{mim}\right]_{1.5} \mathrm{PW}_{4} \mathrm{O}_{24}$ floating in the solution; (b) Homogeneous phase during the reaction; (c) At the end of reaction and the catalyst has precipitated. 
Table 4

Reusability of $\left[\mathrm{D}_{12} \mathrm{mim}\right]_{1.5} \mathrm{PW}_{4} \mathrm{O}_{24}$ catalyst for the epoxidation of cyclohexene with $\mathrm{H}_{2} \mathrm{O}_{2}$ in acetonitrile and dichloromethane.

\begin{tabular}{lccccc}
\hline Reuse & \multicolumn{2}{c}{ In acetonitrile } & & \multicolumn{2}{c}{ In dichloromethane } \\
\cline { 2 - 3 } \cline { 5 - 6 } 1 & $X / \%$ & $S / \%$ & & $X / \%$ & $S / \%$ \\
\hline 2 & 97.7 & 96.3 & & 98.8 & 96.6 \\
3 & 92.1 & 98.2 & & 97.5 & 98.3 \\
4 & 81.5 & 96.7 & & 93.6 & 97.8 \\
\cline { 5 - 6 } & 72.4 & 97.3 & & 89.2 & 96.2 \\
\hline
\end{tabular}

Reaction conditions: $0.1 \mathrm{~g}$ catalyst, $9 \mathrm{mmol}$ cyclohexene, $3 \mathrm{mmol} \mathrm{H}_{2} \mathrm{O}_{2}$, $10 \mathrm{~mL}$ solvent, $60^{\circ} \mathrm{C}, 4 \mathrm{~h}$.

be reused. Table 4 shows the reusability of $\left[\mathrm{D}_{12} \mathrm{mim}\right]_{1.5} \mathrm{PW}_{4} \mathrm{O}_{24}$ for the epoxidation of cyclohexene with $\mathrm{H}_{2} \mathrm{O}_{2}$ in acetonitrile and dichloromethane. In dichloromethane, the catalyst gave $89.2 \%$ conversion after four runs, and recovery of the catalyst was greater than $80 \%$, indicating good reusability. In acetonitrile, the conversion decreased from $97.7 \%$ to $72.4 \%$ between the first and fourth runs. Compared with dichloromethane, the reusability in acetonitrile was relatively poor, which may be due to the catalyst leaching into the highly polar reaction media during the runs. To confirm this, an experiment was carried out in acetonitrile under the reaction conditions. Conversion of $29.4 \%$ (calculated by the decrease in the amount of cyclohexene, Conversion $=($ mol epoxide product + mol byproducts $) /$ (mol initial cyclohexene) $\times 100 \%$ ) was obtained for reaction time of $4 \mathrm{~h}$. Then, the solid catalyst was filtered, and the reaction was continued for another $4 \mathrm{~h}$ with excess $\mathrm{H}_{2} \mathrm{O}_{2}$ added to the homogeneous filtrate, which resulted in conversion of $37.5 \%$ (calculated by the decrease in the amount of cyclohexene). This result confirms that the catalyst leached into the reaction media, and the leached species act as active sites. Therefore, the weakly polar organic solvent dichloromethane is more suitable for the catalytic reaction system than acetonitrile.

FT-IR analysis shows that the IR spectra of the recovered catalyst (Fig. 6(2) and (3)) were generally consistent with the spectrum of the fresh catalyst (Fig. 6(1)). However, the intensity of the peaks at $1150-1650 \mathrm{~cm}^{-1}$, which are due to the organic components, of the catalyst recovered from acetonitrile were

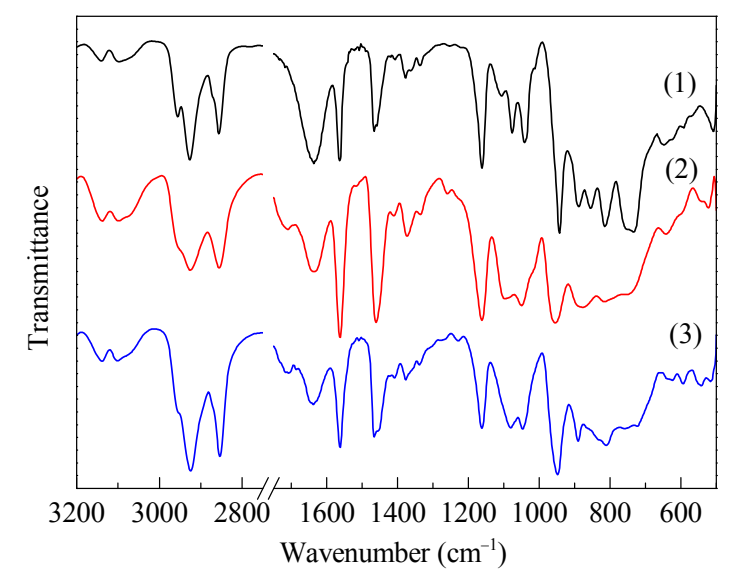

Fig. 6. FT-IR spectra of fresh $\left[\mathrm{D}_{12} \mathrm{mim}\right]_{1.5} \mathrm{PW}_{4} \mathrm{O}_{24} \quad(1)$, reused $\left[\mathrm{D}_{12} \mathrm{mim}\right]_{1.5} \mathrm{PW}_{4} \mathrm{O}_{24}$ in $\mathrm{CH}_{3} \mathrm{CN}(2)$, and reused $\left[\mathrm{D}_{12} \mathrm{mim}\right]_{1.5} \mathrm{PW}_{4} \mathrm{O}_{24}$ in $\mathrm{CH}_{2} \mathrm{Cl}_{2}$ (3).
Table 5

Epoxidation of various olefins with $\mathrm{H}_{2} \mathrm{O}_{2}$ over the $\left[\mathrm{D}_{12} \mathrm{mim}\right]_{1.5} \mathrm{PW}_{4} \mathrm{O}_{24}$ catalyst.

\begin{tabular}{lcc}
\hline Olefin & $X / \%$ & $S / \%$ \\
\hline Cyclohexene $^{\mathrm{a}}$ & 97.7 & 96.3 \\
Cyclooctene $^{\mathrm{a}}$ & $\geq 99$ & $\geq 99$ \\
Styrene $^{\mathrm{b}}$ & 87.2 & 80.2 \\
1-Octene $^{\mathrm{b}}$ & 68.1 & 97.2 \\
\hline Reaction conditions: $0.1 \mathrm{~g}$ catalyst, $9 \mathrm{mmol}$ substrate, $3^{\mathrm{mmol} \mathrm{H}_{2} \mathrm{O}_{2}, 10}$ \\
mL acetonitrile; $^{\mathrm{a}} 60^{\circ} \mathrm{C}, 4 \mathrm{~h} ;{ }^{\mathrm{b}} 70^{\circ} \mathrm{C}, 6 \mathrm{~h}$.
\end{tabular}

larger relative to the peaks of the heteropolyanion. The intensity of the peaks in the same range for the catalyst recovered from dichloromethane were almost the same as the peaks in the spectrum of the heteropolyanion, indicating that the heteropolyanion leached into acetonitrile. In addition, the peak at $852 \mathrm{~cm}^{-1}$ in the heteropolyanion spectrum disappeared in the recycled catalyst, indicating that the catalyst precipitates out of the reaction system when $\mathrm{H}_{2} \mathrm{O}_{2}$ was used up.

\subsection{Catalytic performance of $\left[\mathrm{D}_{12} \mathrm{mim}\right]_{1.5} \mathrm{PW}_{4} \mathrm{O}_{24}$ for other olefins}

To investigate the scope of the $\left[\mathrm{D}_{12} \mathrm{mim}\right]_{1.5} \mathrm{PW}_{4} \mathrm{O}_{24}$ catalyst for epoxidation reactions, the substrates cyclooctene, 1-octene, and styrene were also investigated, and the results are shown in Table 5. During the reaction processes, phase transfer was clearly observed, and high olefin conversion and epoxide product selectivity were obtained. Therefore, the [D $\left.\mathrm{D}_{12 \mathrm{mim}}\right]_{1.5} \mathrm{PW}_{4} \mathrm{O}_{24}$ catalyst was successfully applied to the epoxidation of various olefins using $\mathrm{H}_{2} \mathrm{O}_{2}$, and good to excellent activity and selectivity were obtained in all cases. In particular, for the difficult epoxidation of styrene, the $\left[\mathrm{D}_{12} \mathrm{mim}\right]{ }_{1.5} \mathrm{PW}_{4} \mathrm{O}_{24}$ catalyst gave $87.2 \%$ conversion and $80.2 \%$ selectivity.

\section{Conclusions}

We synthesized the POM-based hybrid material $\left[\mathrm{D}_{n} \mathrm{mim}\right]_{1.5} \mathrm{PW}_{4} \mathrm{O}_{24}$ by combining the dicationic alkylimidazolium cation with the peroxopolyoxometalate anion, and measured the catalytic activity of the material in the epoxidation of olefins with $\mathrm{H}_{2} \mathrm{O}_{2}$. The catalysts proved to be temperature-controlled phase transfer catalysts in common polar organic solvents and reaction-controlled phase transfer catalysts in weakly polar organic solvents. The chain length of the $\mathrm{R}$ group of the imidazolium cation significantly affected the phase transfer catalysis behavior and the catalyst activity for epoxidation. The $\left[\mathrm{D}_{12} \mathrm{~min}\right]_{1.5} \mathrm{PW}_{4} \mathrm{O}_{24}$ catalyst modified by the dodecyl dicationic imidazolium cation showed very high conversion and selectivity, coupled with convenient recovery and good reusability.

\section{References}

[1] Espinal L, Suib S L, Rusling J F. J Am Chem Soc, 2004, 126: 7676

[2] Li N N, Liu Y M, Wu H H, Li X H, Xie W, Zhao Z L, Wu P, He M Y. Chin J Catal (李宁宁, 刘月明, 吴海虹, 李晓红, 谢伟, 赵忠林, 吴鹏, 何 鸣元. 催化学报), 2008, 29: 102 


\title{
Graphical Abstract
}

Chin. J. Catal., 2013, 34: 2236-2244 doi: 10.1016/S1872-2067(12)60697-4

\section{Synthesis of dicationic alkyl imidazolium peroxopolyoxotung- sten-based phase transfer catalyst and its catalytic activity for olefin epoxidation}

Jianghao Wu, Pingping Jiang*, Yan Leng, Yuanyuan Ye, Xiaojie Qin Jiangnan University

Peroxopolyoxotungsten-based hybrid catalysts modified by the dicationic long-chain alkyl imidazolium cation were synthesized and used as the phase transfer catalyst for cyclohexene epoxidation reactions.

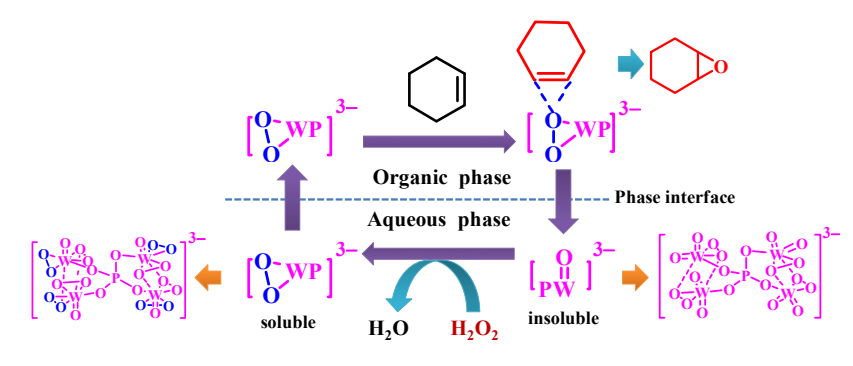

[3] Lu X N, Lin H Q, Yuan Y Z. Chin J Catal (卢新宁, 林海强, 袁友珠. 催化学报), 2010, 31: 1457

[4] De Faveri G, Ilyashenko G, Watkinson M. Chem Soc Rev, 2011, 40: 1722

[5] Mizuno N, Yamaguchi K, Kamata K. Coordin Chem Rev, 2005, 249: 1944

[6] Wang Y, Jiang P P, Zhang W J, Zheng J W. Appl Surf Sci, 2013, 270: 531

[7] Balula S S, Santos I C M S, Cunha-Silva L, Carvalho A P, Pires J, Freire C, Cavaleiro J A S, de Castro B, Cavaleiro A M V. Catal Today, 2013, 203: 95

[8] Cai W J, Zhou Y, Bao R L, Yue B, He H Y. Chin J Catal (蔡雯佳, 周琰, 包任烈, 岳斌, 贺鹤勇. 催化学报), 2013, 34: 193

[9] Amini M, Haghdoost M M, Bagherzadeh M. Coordin Chem Rev, 2013, 257: 1093

[10] Saisaha P, de Boer J W, Browne W R. Chem Soc Rev, 2013, 42: 2059

[11] Gao P F, Zhang T M, Zhou Y, Zhao Y X. Chin J Catal (高鹏飞, 张铁明, 周媛，赵永祥. 催化学报), 2011, 32: 166

[12] Ishii Y, Yamawaki K, Yoshida T, Ura T, Ogawa M. J Org Chem, 1987, 52: 1868
[13] Venturello C, Alneri E, Ricci M. J Org Chem, 1983, 48: 3831

[14] Xi Z W, Zhou N, Sun Y, Li K L. Science, 2001, 292: 1139

[15] Zhang H Y, Lü Y, Li J, Gao S, Xi Z W. Chin J Catal (张恒耘, 吕迎, 李 军, 高爽, 奚祖威. 催化学报), 2010, 31: 1253

[16] Qiao Y X, Hou Z S, Li H, Hu Y, Feng B, Wang X R, Hua L, Huang Q F. Green Chem, 2009, 11: 1955

[17] Biboum R N, Doungmene F, Keita B, de Oliveira P, Nadjo L, Lepoittevin B, Roger P, Brisset F, Mialane P, Dolbecq A, Mbomekalle I M, Pichon C, Yin P C, Liu T B, Contant R. J Mater Chem, 2012, 22: 319

[18] Hua L, Qiao Y X, Chen J Z, Zhu W W, Guo L, Zhang R, Hou Z S. Chin Sciencepaper (华丽, 乔云香, 陈吉忠, 朱闻闻, 郭立, 张然, 侯震 山. 中国科技论文), 2012, 7: 949

[19] Li H, Hou Z S, Qiao Y X, Feng B, Hu Y, Wang X R, Zhao X G. Catal Commun, 2010, 11: 470

[20] Venturello C, D'Aloisio R. J Org Chem, 1988, 53: 1553

[21] Duncan D C, Chambers R C, Hecht E, Hill C L.J Am Chem Soc, 1995, 117: 681

[22] Venturello C, D'Aloisio R, Bart J C J, Ricci M. J Mol Catal, 1985, 32: 107

\section{双核烷基咪唑过氧磷钨酸盐相转移催化剂合成及催化烯烃环氧化性能}

\author{
吴江浩, 蒋平平 ${ }^{*}$, 冷炎, 叶媛园, 秦晓洁 \\ 江南大学化学与材料工程学院, 食品胶体与生物技术教育部重点实验室, 江苏无锡 214122
}

摘要: 合成并表征了一类双核长链烷基咪唑阳离子修饰的过氧磷铇杂多酸盐催化剂 $\left[\mathrm{D}_{n} \mathrm{~min}_{1.5} \mathrm{PW}_{4} \mathrm{O}_{24}\right.$, 考察了催化剂在过氧化氢 为氧源的烯烃环氧化反应中的催化活性. 研究表明, 这类催化剂在反应过程中表现出相转移催化现象, 并具有较高的催化活性和 选择性. 其中, 双核十二烷基咪唑杂多酸盐催化剂 $\left[\mathrm{D}_{12} \mathrm{~min}\right]_{1.5} \mathrm{PW}_{4} \mathrm{O}_{24}$ 的活性最佳, 其环已烯转化率和环氧环己烷选择性分别达到 97.7\%和 $96.3 \%$. 催化剂在经过简单离心分离后可重复使用, 重复使用 4 次后环己烯转化率和环氧环已烷选择性仍可分别达到 $72.4 \%$ 和 $97.2 \%$. 催化剂 $\left[\mathrm{D}_{12} \mathrm{~min}\right]_{1.5} \mathrm{PW}_{4} \mathrm{O}_{24}$ 在其它几种烯烃的环氧化反应中均表现出相转移催化特性, 且具有较高的催化活性. 关键词: 双核离子液体; 多金属氧酸盐; 烯烃; 环氧化反应; 相转移催化剂

收稿日期: 2013-06-17. 接受日期: 2013-08-21. 出版日期: 2013-12-20.

*通讯联系人. 电话: (0510)85917090; 传真: (0510) 85913617; 电子信箱: ppjiang@jiangnan.edu.cn 基金来源：国家科技支撑计划(2012BAD32B03); 江苏省产学研前瞻性联合研究项目(BY2013015-10).

本文的英文电子版由Elsevier出版社在ScienceDirect上出版(http://www.sciencedirect.com/science/journal/18722067).

\section{1. 前言}

烯烃环氧化产物是一类极其重要的有机原料和中
间体, 被广泛应用于精细化工、石油化工和有机合成等 领域 ${ }^{[1-3]}$. 近年来, 以环境友好的 $\mathrm{H}_{2} \mathrm{O}_{2}$ 为氧源, 开发反应 条件温和、高效可回收和重复使用的绿色环氧化催化剂 
成为人们研究的热点 ${ }^{[4]}$. 在以过氧化氢为氧源的烯烃环 氧化反应体系中, 目前研究最多的是钿、铇、锰、钒化 合物, 钛硅分子笁和杂多化合物(POMs) 等 ${ }^{[5-11]}$ 催化剂. 其中, Venturello-Ishii $\left(\left\{\mathrm{PO}_{4}\left[\mathrm{WO}\left(\mathrm{O}_{2}\right)_{2}\right]_{4}\right\}^{3-}\right)$ 型杂多酸 (HPA)被证明是实现清洁环氧化过程的一种有效催化 剂 ${ }^{[12,13]}$. 然而, Venturello-Ishii型杂多酸易溶于极性溶剂, 难以用作多相催化剂. 自从奚祖威等 ${ }^{[14]}$ 发现杂多酸的 季铵盐在烯烃的环氧化反应中能够表现出 $\mathrm{H}_{2} \mathrm{O}_{2}$ 反应控 制的相转移现象以来, 均相催化多相分离的相转移催化 过程开始受到了人们的高度关注 ${ }^{[15-19]}$. 这类催化剂不仅 具备均相催化剂高活性、高选择的特性, 同时具有非均 相催化剂易分离的优点.

本文通过分子改性方法, 将不同烷基链长的双核咪 唑阳离子与Venturello-Ishii型过氧磷铇酸结合, 制备了 一类双核长链烷基咪唑阳离子修饰的磷铇杂多酸杂化 催化剂 $\left[\mathrm{D}_{n} \mathrm{~min}\right]_{1.5} \mathrm{PW}_{4} \mathrm{O}_{24}$. 采用红外光谱(FT-IR)、热重 (TG)、元素分析及核磁共振氢谱 $\left({ }^{1} \mathrm{H} N \mathrm{NR}\right)$ 等手段对其进 行了表征, 并考察了其在以过氧化氢为氧源的烯烃环氧 化反应中的催化性能.

\section{2. 实验部分}

\section{1. 催化剂的制备}

\subsection{1. $N$-烷基咪唑的合成}

以十二烷基咪唑为例, 将咪唑 $(2.3 \mathrm{~g}, 33.9 \mathrm{mmol})$ 溶 于 $25 \mathrm{~mL} \mathrm{~N}, N$-二甲基甲酰胺(DMF)中, 加入氢化钠 $(1.4 \mathrm{~g}$, $62 \mathrm{mmol}$ ), 搅拌 $2 \mathrm{~h}$, 加入 $25 \mathrm{~mL}$ 溴代十二烷 $(7 \mathrm{~g}, 28 \mathrm{mmol}$ ) 的DMF溶液, 于 $60^{\circ} \mathrm{C} 反$ 应 $6 \mathrm{~h}$. 反应后过滤, 得到的滤液 经饱和食盐水洗涤, 无水硫酸镁干燥, 用旋转蒸发仪除 去溶剂得 $\mathrm{N}$-十二烷基咪唑. ${ }^{1} \mathrm{H} \mathrm{NMR}\left(400 \mathrm{MHz}, \mathrm{CDCl}_{3}\right)$ $\delta=7.45(\mathrm{~s}, 1 \mathrm{H}, \mathrm{CH}), 7.04(\mathrm{~s}, 1 \mathrm{H}, \mathrm{CH}), 6.90(\mathrm{~s}, 1 \mathrm{H}, \mathrm{CH})$, $3.91\left(\mathrm{t}, J=7.1 \mathrm{~Hz}, 2 \mathrm{H}, \mathrm{CH}_{2}\right), 1.77(\mathrm{~m}, J=13.5 \mathrm{~Hz}, 2 \mathrm{H}$, $\left.\mathrm{CH}_{2}\right), 1.27\left(\mathrm{~m}, J=13.1 \mathrm{~Hz}, 18 \mathrm{H}, \mathrm{CH}_{2}\right), 0.88(\mathrm{t}, J=6.7 \mathrm{~Hz}$, $\left.3 \mathrm{H}, \mathrm{CH}_{3}\right)$.

\subsection{2. 双核烷基咪唑离子液体前驱体的合成}

以双核十二烷基咪唑盐为例, 将 $N$-十二烷基咪唑 (4.72 g, $20 \mathrm{mmol}$ )和1,4-二溴丁烷 $(2.16 \mathrm{~g}, 10 \mathrm{mmol}$ )溶于 $25 \mathrm{~mL}$ 异丙醇中, $80^{\circ} \mathrm{C}$ 回流 $24 \mathrm{~h}$, 用旋转蒸发仪除去溶 剂, 所得固体用乙醚洗涤, 干燥, 得到双核十二烷基咪唑 离子液体前躯体, 记为 $\left[\mathrm{D}_{12} \mathrm{~min}\right] \mathrm{Br}_{2} .{ }^{1} \mathrm{H} \mathrm{NMR}(400 \mathrm{MHz}$, $\left.\mathrm{CDCl}_{3}\right) \delta=10.18\left(\mathrm{~s}, 2 \mathrm{H}, \mathrm{CH}_{2}\right), 8.12(\mathrm{~s}, 2 \mathrm{H}, \mathrm{CH}), 7.29(\mathrm{~s}$, $2 \mathrm{H}, \mathrm{CH}), 4.58\left(\mathrm{~s}, 4 \mathrm{H}, \mathrm{CH}_{2}\right), 4.27$ (t, $J=7.5 \mathrm{~Hz}, 4 \mathrm{H}, \mathrm{CH}_{2}$ ), $2.19\left(\mathrm{~s}, 4 \mathrm{H}, \mathrm{CH}_{2}\right), 1.90\left(\mathrm{~d}, J=6.4 \mathrm{~Hz}, 4 \mathrm{H}, \mathrm{CH}_{2}\right), 1.25(\mathrm{~m}$,
$36 \mathrm{H}, \mathrm{CH}_{2}$ ), $0.88\left(\mathrm{t}, J=6.8 \mathrm{~Hz}, 6 \mathrm{H}, \mathrm{CH}_{3}\right)$.

\subsection{3. 双核烷基咪唑磷铇酸盐的合成 ${ }^{[20]}$}

将铇酸 $(2.5 \mathrm{~g}, 10 \mathrm{mmol})$ 加入到 $7.93 \mathrm{~g}(70 \mathrm{mmol})$ $30 \%$ 的过氧化氢中, 加热至 $60{ }^{\circ} \mathrm{C}$, 搅拌反应直至溶液颜 色变成浅黄色, 过滤, 冷却至室温, 将滤液稀释至 $30 \mathrm{~mL}$. 加入 $0.62 \mathrm{~g} 40 \%(\mathrm{wt} \%) \mathrm{H}_{3} \mathrm{PO}_{4}(2.5 \mathrm{mmol})$, 然后将 $40 \mathrm{~mL}$ 双核离子液体 $(3.75 \mathrm{mmol})$ 的 $\mathrm{CH}_{2} \mathrm{Cl}_{2}$ 溶液逐滴加入到上 述反应体系中, 反应 $15 \mathrm{~min}$. 分液, 有机相用无水硫酸钠 干燥 $12 \mathrm{~h}$, 用旋转蒸发仪除去溶剂, 得到浅黄色固体产 物, 记为 $\left[\mathrm{D}_{12} \mathrm{mim}\right]_{1.5} \mathrm{PW}_{4} \mathrm{O}_{24}$, 合成路线如图式1所示.

\section{2. 催化剂的表征}

采用加拿大ABB公司FTLA2000型傅里叶变换红外 光谱仪测定样品的 FT-IR 谱 (KBr 压片, 扫描范围 4000-500 $\mathrm{cm}^{-1}$ ); 采用瑞士梅特勒公司 TGA/1100SF型综 合热分析仪对样品进行 TG分析, 样品放置在氮气气氛 中, 以 $10{ }^{\circ} \mathrm{C} / \mathrm{min}$ 的速率升温; 采用德国Elementar公司 Vario ELIII型元素分析仪进行CHN元素分析; 采用德国 Bruker公司AVANCE III $(400 \mathrm{MHz})$ 型核磁共振谱议对 有机阳离子进行 ${ }^{1} \mathrm{H}$ NMR分析.

\section{3. 环己烯氧化反应}

将 $0.1 \mathrm{~g}$ 催化剂, $9 \mathrm{mmol}$ 环已烯和 $10 \mathrm{~mL}$ 乙腈加入到 $25 \mathrm{~mL}$ 单口烧瓶中, 升温至 $60^{\circ} \mathrm{C}, 10 \mathrm{~min}$ 内加入 $3 \mathrm{mmol}$ $30 \% \mathrm{H}_{2} \mathrm{O}_{2}, 60{ }^{\circ} \mathrm{C}$ 反应 $4 \mathrm{~h}$ 后停止反应. 反应液中的反应 物和反应产物使用气相色谱仪通过内标法进行定量分 析(温岭市福立分析仪器有限公司GC9790 II 型气相色谱 仪, FID检测器, SE-54色谱柱, $30 \mathrm{~m} \times 0.32 \mathrm{~mm} \times 0.4 \mu \mathrm{m}$ ). 将催化剂离心分离后, 无需做任何再生处理, 直接用于 下一次反应, 考察催化剂的重复使用性能. 环已烯转化 率 $(X)$ 和环氧环已烷的选择性 $(S)$ 按以下方法计算:

$X=($ 环氧产物摩尔量 + 副产物摩尔量 $) /($ 过氧化氢 初始量) $\times 100 \%$

$S=($ 环氧产物摩尔量 $) /($ 环氧产物摩尔量 + 副产物 摩尔量) $\times 100 \%$

所有烯烃转化率和选择性均按以上方法计算.

\section{3. 结果与讨论}

\section{1. 催化剂结构与热稳定性}

图 1 为所得催化剂 $\left[\mathrm{D}_{n} \mathrm{~min}\right]_{1.5} \mathrm{PW}_{4} \mathrm{O}_{24}$ 的 $\mathrm{TG}$ 曲线. 可 以看出, 这类催化剂在 $200{ }^{\circ} \mathrm{C}$ 前的 I 区基本稳定, 少 量失重是由于催化剂中结合水的脱除, 说明该类催化剂 具有良好的热稳定性; $250-600{ }^{\circ} \mathrm{C}$ 间 II 区的明显失重 (失重率 22\%-47\%) 是由于催化剂中有机阳离子组分的 
分解造成的, 并且随着阳离子烷基链的增长, 失重逐渐 增加. 不同有机杂多酸盐催化剂的失重率与相应的 CHN元素分析结果基本一致, 并且与理论计算值基本相 符(表1). 从上述 TG和 CHN元素分析的结果可知, 所合 成催化剂中双核离子液体阳离子与杂多阴离子的摩尔 比为 $1.5: 1$, 具有图式1中所示的催化剂结构式.

\subsection{FT-IR结果}

图2为催化剂的FT-IR谱. 所合成的咪唑杂多酸盐催 化剂均出现明显的 $\left\{\mathrm{PO}_{4}\left[\mathrm{WO}\left(\mathrm{O}_{2}\right)_{2}\right]_{4}\right\}^{3-}$ 阴离子的特征吸 收峰: 1077 和 $1039(\mathrm{P}-\mathrm{O}), 942(\mathrm{~W}=\mathrm{O}), 889\left(\mathrm{~W}-\mathrm{O}_{\mathrm{b}}-\mathrm{W}\right)$, $852(\mathrm{O}-\mathrm{O}), 811\left(\mathrm{~W}-\mathrm{O}_{\mathrm{c}}-\mathrm{W}\right)$ 和 $591\left(\mathrm{~W}-\mathrm{O}_{\mathrm{b}}-\mathrm{O}\right) \mathrm{cm}^{-1}$. 同时 谱图上可以清楚地观察到阳离子的特征吸收峰, 例如: 3145 和 $3099 \mathrm{~cm}^{-1}$ 是咪唑环上 $\mathrm{C}-\mathrm{H}$ 的振动吸收峰; 2960 , 2918 和 $2848 \mathrm{~cm}^{-1}$ 是烷基链上 $\mathrm{C}-\mathrm{H}$ 的振动吸收峰; 1562 和 $1464 \mathrm{~cm}^{-1}$ 附近为咪唑环的骨架振动. 由此可见, 双核 离子液体阳离子与 $\left\{\mathrm{PO}_{4}\left[\mathrm{WO}\left(\mathrm{O}_{2}\right)_{2}\right]_{4}\right\}^{3-}$ 阴离子通过离子 交换结合后, 形成了一类有机杂多酸盐杂化催化剂, 且 有机和无机组分的结构保持完好. 另外, 这类催化剂在 $852 \mathrm{~cm}^{-1}$ 均出现了过氧化铇中 $\mathrm{O}-\mathrm{O}$ 键的特征峰, 该活性 组分被认为是烯烃环氧化反应的主要活性中心 ${ }^{[21,22]}$, 说 明所合成的双核烷基咪唑磷铇酸盐催化剂具有良好的 烯烃环氧化的催化活性中心.

\section{3. 不同催化剂的活性比较}

乙腈是氧化反应中一种常用的有机溶剂, 因此考察 了不同催化剂在乙腈溶剂中催化环已烯环氧化的催化 性能, 结果列于表2. 表中数据显示, 咪唑阳离子中烷基 的链长显著影响着催化剂的环氧化活性. 当双核甲基咪 唑杂多酸盐 $\left(\left[\mathrm{D}_{1} \mathrm{mim}\right]_{1.5} \mathrm{PW}_{4} \mathrm{O}_{24}\right)$ 用作催化剂时, 仅获得了 $69.2 \%$ 的环已烯转化率和 $98.6 \%$ 的选择性; 随着烷基链 长度的增加, 催化剂的烯烃环氧化活性也显著增加, $\left[\mathrm{D}_{4} \mathrm{mim}\right]_{1.5} \mathrm{PW}_{4} \mathrm{O}_{24},\left[\mathrm{D}_{8} \mathrm{mim}\right]_{1.5} \mathrm{PW}_{4} \mathrm{O}_{24}$ 和 $\left[\mathrm{D}_{12} \mathrm{mim}\right]_{1.5} \mathrm{PW}_{4} \mathrm{O}_{24}$ 分别给出了 $78.5 \%, 92.1 \%$ 和 $97.7 \%$ 的环已烯转化率, 且选 择性均大于 $96 \%$. 说明结构中长的烷基链可增加催化剂 的亲油性, 从而有利于反应物分子与催化活性组分接触. 然而, 当催化剂链长进一步增长, 双核十六烷基咪唑杂 多酸的催化活性反而有所下降, 给出了 $89.2 \%$ 的转化率 和 $97.2 \%$ 的选择性. 这可能是由于过长的烷基链增加了 催化剂的空间位阻和催化剂与反应物间的传质阻力, 从 而导致较低的环氧化催化活性. 从上述结果可以看出, 双核十二烷基咪唑杂多酸盐为性能最优异的以 $\mathrm{H}_{2} \mathrm{O}_{2}$ 为 氧源的环已烯环氧化催化剂, 在乙腈溶剂中, $60{ }^{\circ} \mathrm{C}$ 下反 应4 h, 转化率和选择性分别达到 $97.7 \%$ 和 $96.3 \%$.
在反应过程中, 上述双核烷基咪唑杂多酸盐催化剂 表现出了截然不同的催化行为. 催化剂 $\left[\mathrm{D}_{4} \mathrm{mim}\right]_{1.5} \mathrm{PW}_{4} \mathrm{O}_{24},\left[\mathrm{D}_{8} \mathrm{mim}\right]_{1.5} \mathrm{PW}_{4} \mathrm{O}_{24},\left[\mathrm{D}_{12} \mathrm{mim}\right]_{1.5} \mathrm{PW}_{4} \mathrm{O}_{24}$ 和 $\left[\mathrm{D}_{16} \mathrm{mim}\right]_{1.5} \mathrm{PW}_{4} \mathrm{O}_{24}$ 均表现出相转移催化现象. 如图3 所示, 在反应刚开始, 催化剂不溶于反应物环已烯和溶 剂乙腈; 然而, 当 $\mathrm{H}_{2} \mathrm{O}_{2}$ 加入到反应体系之后, 催化剂逐 渐溶解, 反应体系变成了均一透明的均相溶液; 当反应 结束后, 将反应体系降至室温, 反应体系开始变浑浊, 催 化剂逐渐从反应体系中 析出沉至烧瓶底部. 然而双核 甲基咪唑磷铇酸盐则没有出现相转移催化现象, 在整个 反应过程中均呈现非均相催化过程, 这也许正是造成其 环氧化活性较低的主要原因. 由此可见, 长链烷基修饰 的双核咪唑杂多酸盐对该催化剂在环氧化催化体系中 的相转移催化行为起到了至关重要的作用, 从而赋予了 催化剂优异的催化活性和选择性.

在氯仿类溶剂中, 季铵盐型磷铇杂多化合物能与过 氧化氢作用形成易溶于反应体系的过氧化活性中间体, 并随着 $\mathrm{H}_{2} \mathrm{O}_{2}$ 的消耗, 催化剂逐渐恢复成原先结构的催化 剂, 从反应体系中析出, 从而形成反应控制的相转移催 化体系 ${ }^{[14]}$. 为了证明本文所合成的双核咪唑磷铇酸盐 催化剂在乙腈溶剂中与 $\mathrm{H}_{2} \mathrm{O}_{2}$ 作用同样形成了易溶于反 应体系的过氧磷铇活性组分 $\left(\left\{\mathrm{PO}_{4}\left[\mathrm{WO}\left(\mathrm{O}_{2}\right)_{2}\right]_{4}\right\}^{3-}\right)$, 我们 对 $\mathrm{H}_{2} \mathrm{O}_{2}$ 处理过的双核十二烷基咪唑磷铇酸盐进行了 FT-IR表征. 如图4所示, 新鲜催化剂在 $852 \mathrm{~cm}^{-1}$ 处出现 较弱的过氧化铇 $\mathrm{O}-\mathrm{O}$ 键的伸缩振动峰, 而该峰的强度在 $\mathrm{H}_{2} \mathrm{O}_{2}$ 处理后明显增强, 意味着双核咪唑磷钨酸盐经 $\mathrm{H}_{2} \mathrm{O}_{2}$ 处理后, 形成了过氧磷铇活性组分 $\left(\left\{\mathrm{PO}_{4}\left[\mathrm{WO}\left(\mathrm{O}_{2}\right)_{2}\right]_{4}\right\}^{3-}\right)$, 因此在反应过程中, 当 $\mathrm{H}_{2} \mathrm{O}_{2}$ 加入后, 催化剂逐渐溶解, 形 成了均相催化体系. 然而, 当反应结束后, 双核咪唑磷铇 酸盐催化剂并没有自动析出, 而是在反应体系降温后才 析出. 因此, 双核咪唑磷铇酸盐在乙腈溶剂中导致一个 温度控制的相转移催化环已烯环氧化体系, 并且相较于 传统均相催化体系催化剂不能回收和非均相催化体系 催化剂催化效率低下的缺点, 该催化体系能够较好地回 收体系中的催化剂, 并且具有优异的催化效果.

\section{4. $\left[\mathrm{D}_{12} \mathrm{mim}\right]_{1.5} \mathrm{PW}_{4} \mathrm{O}_{24}$ 在不同溶剂中的催化活性及反 应相态}

考察了不同溶剂体系对催化剂 $\left[\mathrm{D}_{12} \mathrm{mim}\right]_{1.5} \mathrm{PW}_{4} \mathrm{O}_{24}$ 相转移催化行为的影响. 如表 3 所示, 当乙腈、乙酸乙酯、 二氯甲烷和 1,2-二氯乙烷作溶剂时, 双核十二烷基咪唑 磷铇酸盐催化环已烯的环氧化反应均出现了相转移催 化现象, 且环己烯转化率和环氧环已烷选择性分别在 
$97 \%$ 和 $96 \%$ 以上. 其中, 乙酸乙酯作为溶剂时, 反应体系 表现出与乙腈作溶剂时相似的温度控制的相转移现象, 即反应结束后, 反应体系降至室温, 催化剂逐渐从反应 体系中析出. 而二氯甲烷和1,2-二氯乙烷作为溶剂时, 当体系中 $\mathrm{H}_{2} \mathrm{O}_{2}$ 消耗完毕, 催化剂自动从反应体系中析出 (图5), 无需将反应液降至室温. 这与前人报道的在氯仿 类溶剂中 $\mathrm{H}_{2} \mathrm{O}_{2}$ 反应控制的磷铇酸季铵盐催化烯烃环氧 化相转移催化现象相一致 ${ }^{[14]}$. 另外, 当环己烷作为溶剂 时, 整个反应过程呈现液-固两相催化体系, 这可能是由 于过氧磷铇活性组分难溶于极性过低的环已烷溶剂, 从 而导致较低的催化活性. 由此可见, 本文设计合成的双 核烷基咪唑磷铇酸盐催化剂在常见的极性有机溶剂中 表现出温度控制的相转移催化过程, 在弱极性有机溶剂 中表现出反应控制的相转移催化过程.

\section{5. $\left[\mathrm{D}_{12} \mathrm{mim}\right]_{1.5} \mathrm{PW}_{4} \mathrm{O}_{24}$ 的循环使用性}

反应结束后, 可通过离心分离出催化剂直接用于下 一次反应. 对由 $\left[\mathrm{D}_{12} \mathrm{mim}\right]_{1.5} \mathrm{PW}_{4} \mathrm{O}_{24}$ 、环已烯、过氧化氢 和乙腈/二氯甲烷构成的催化体系, 分别进行了催化剂的 循环性能测试, 结果如表4所列. 在二氯甲烷做溶剂的催 化体系中, 催化剂重复使用 4 次后, 环已烯的转化率虽有 所下降, 但仍能达到 $89.2 \%$, 说明 $\left[\mathrm{D}_{12} \mathrm{mim}\right]_{1.5} \mathrm{PW}_{4} \mathrm{O}_{24}$ 在二 氯甲烷体系中具有良好的重复使用性, 且在使用 4 次后 催化剂的回收率大于 $80 \%$. 对于乙腈作为溶剂的催化体 系, 催化剂在重复使用 4 次后, 环已烯的转化率由原来的 $97.7 \%$ 降为 $72.4 \%$, 选择性为 $97.3 \%$. 催化剂的重复使用 性能相较于在二氯甲烷溶剂中有所降低, 这可能是由于 乙腈较强的极性导致催化剂在重复使用过程中发生了 部分流失. 为了印证这一猜想, 我们在乙腈溶剂中环氧 化反应 $4 \mathrm{~h}$ 后将催化剂分离, 然后加入过量过氧化氢继续 反应 $4 \mathrm{~h}$, 发现环已烯的转化率从 $29.4 \%$ 提高到 $37.5 \%$ (以 环己烯总量计算, 转化率 $=($ 环氧产物摩尔量 + 副产物摩 尔量 $)$ (环己烯初始量 $) \times 100 \%$ ), 说明催化剂在乙腈溶剂 中发生部分流失, 且流失部分起到活性中心的作用. 因 此, 弱极性的二氯甲烷相较于极性有机溶剂乙腈更适合 于该催化反应体系.

通过新鲜催化剂与回收催化剂的红外光谱对比发 现(图6), 回收催化剂与新鲜催化剂的红外谱图基本一 致, 然而, 对于乙腈体系回收的催化剂, 在1650-1150 $\mathrm{cm}^{-1}$ 间有机组分的吸收峰相对于杂多阴离子的特征峰 强度有所增强; 而对于二氯甲烷体系回收的催化剂, 在 此区间有机组分的吸收峰相对于杂多阴离子的特征峰 强度改变不大. 这表明催化剂在乙腈溶剂中重复使用性 能的降低是由于催化剂在重复使用过程中杂多阴离子 的流失所致. 另外, 回收的催化剂在 $852 \mathrm{~cm}^{-1}$ 处的过氧 键 $v(\mathrm{O}-\mathrm{O})$ 特征吸收峰均消失, 说明当 $\mathrm{H}_{2} \mathrm{O}_{2}$ 消耗完毕, 催 化剂从反应体系中析出. 对于乙腈体系回收的催化剂, 在1650-1150 $\mathrm{cm}^{-1}$ 间有机组分的吸收峰相对于杂多阴离 子的特征峰强度有所增强, 这是由于乙腈的强极性致使 催化剂在重复使用过程中部分杂多阴离子溶脱到反应 体系中, 从而导致催化剂的重复使用性能降低.

\section{6. $\left[\mathrm{D}_{12} \mathrm{mim}_{1.5} \mathrm{PW}_{4} \mathrm{O}_{24}\right.$ 催化不同烯烃的反应}

为了考察 $\left[\mathrm{D}_{12} \mathrm{mim}\right]_{1.5} \mathrm{PW}_{4} \mathrm{O}_{24}$ 催化剂在烯烃环氧化 反应中的普适性, 将其应用于不同烯烃(如环辛烯、苯乙 烯和1-辛烯)的环氧化反应中, 结果列于表 5. 由表可以 看出, 在这些催化反应过程中均能观察到催化剂的相转 移现象, 同时获得了较高的烯烃转化率和环氧产物选择 性. 上述研究结果表明, 本文设计合成的双核烷基咪唑 磷铇酸盐催化剂适用于多种烯烃的环氧化反应. 尤其是 对于目前普遍认为比较难的苯乙烯的环氧化反应, 苯乙 烯的转化率和环氧苯乙烯的选择性分别达到 $87.2 \%$ 和 $80.2 \%$.

\section{4. 结论}

将双核长链烷基咪唑阳离子与过氧磷铇酸结合, 合 成了一类有机杂多酸盐催化剂 $\left[\mathrm{D}_{n} \mathrm{mim}\right]_{1.5} \mathrm{PW}_{4} \mathrm{O}_{24}$, 并考 察了这类催化剂在烯烃环氧化反应中的催化性能. 结果 表明, 这类催化剂在极性有机溶剂中表现出温度控制的 相转移催化过程, 在弱极性有机溶剂中表现出反应控制 的相转移催化过程, 且催化剂 $\left[\mathrm{D}_{12} \mathrm{mim}_{1.5} \mathrm{PW}_{4} \mathrm{O}_{24}\right.$ 催化环 己烯环氧化的转化率和环氧环已烷的选择性均大于 $96 \%$. 催化剂在通过简单离心分离后可重复使用, 且在 二氯甲烷溶剂中重复使用 4 次后环已烯的转化率和环氧 环已烷的选择性仍能达到 $89.2 \%$ 和 $96.2 \%$. 催化剂阳离 子中烷基的链长对催化剂的相转移催化行为和催化活 性有重要影响, 其中用十二烷基修饰的磷铇酸盐表现出 优异的催化性能. 